sheepskin on the roof of a hut ; and whilst it is engaged in tearing up the bait it is easily approached and snared." Io. The Gayal (Bibos frontalis). - In the mountainous districts of the oriental region three fine species of wild cattle occur which do not belong strictly to the genus Bos-the supposed progenitors of our domestic herdsbut to a slightly modified form, Bibos of naturalists. One of these - the Gaur-inhabits the Ghauts of Central India, and is the well-known "Bison" of Anglo-Indian sportsmen. The Gaur is very intolerant of captivity, and although many attempts have been made to rear young specimens for transmission to Europe, none of them have ever proved successful. A second species of Bibos, the Bantang ( $B$. javanicus), is found only in the hills of the Malay countries. It is more tractable, and examples of it have occasionally reached Europe alive, though they have not done well in this country.

Of the third Bibos, the Gayal (B. frontalis), we give a figure taken from a fine pair of these animals now in the Zoological Society's Gardens, which were received from the sister Zoological Society of Calcutta. The Gayal, as Jerdon tells us, in a state of nature inhabits the hilly tracts to the east of the Brahmapootra and at the head of the Valley of Assam, extending into the Mishmi Hills and adjacent ranges. It is caught and kept in captivity by the natives very extensively, and to this fact is no doubt due the comparative ease with which specimens of it are brought to Europe.

The Gayal breeds readily with the different forms of Domestic Ox. Many hybrids between the Zebu and Gayal have been produced in former years in the Zoological Society's Menagerie.

\section{SHIPBUILDING A THOUSAND YEARS AGO}

$M$ R. COLIN ARCHER read an interesting paper on $\mathrm{M}$ this subject at the recent meeting of the Institution of Naval Architects, as also at the York meeting of the British Association.

It is a well-known historical fact that as far back as the early part of the Middle Ages, the inhabitants of Scandinavia were a great seafaring nation: in many of the great battles fought between the chiefs and pretenders of that period-and they were not few-we find several hundreds of large war-ships ranged against each other. It seems to have been quite a common practice for the young chiefs, in order to relieve the monotony of life on shore, or to escape the consequences of some lawless act, to equip one or more ships, manned by their retainers, and to launch forth in quest of adventure, plunder, or "the bubble reputation." And these excursions were not always confined to home waters; they were frequently extended not only to the coast countries of the north of Europe, but also to the shores of the Mediterranean. Iceland was discovered about the middle of the ninth century by Norwegian adventurers, and there are good grounds for believing that an expedition starting from Iceland landed and established a colony in the present New England States nearly 500 years before Columbus lived.

But the descriptions which the old Sagas afford of the vessels in which these expeditions were undertaken, and these battles were fought, are very meagre. It was therefore looked upon as an event of great interest when, on excavating a large grave-mound near the entrance to Christiania Fjord, a ship, evidently from the Viking period, was discovered in a wonderful state of preservation. There is reason to believe that this ship, although comparatively small, does not differ materially in her manner of construction or in shape from the more powerful war-ships, or from those used for long voyages. She is probably a true model of the ships which carried Rollo and his brave followers to the coast of Normandy; and it may therefore be assumed that a brief description of her, as she now appears from a shipbuilder's point of view, may not be without interest.

It was not to be expected that a delicate structure such as this Viking ship could remain for eight or ten centuries buried many yards under ground without sustaining some damage, or that she should perfectly retain her original form. It is rather a matter of surprise that the damage is so small as it is. Thanks to careful handling and a judicious arrangement of supports, there is reason to believe that, apart from local strains and contortions of form, the hull as it now stands represents very closely the ship as she appeared when put into the ground. Mr. Archer has taken off her lines with as much accuracy as circumstances would permit, and, referring to these lines, he explains the chief peculiarities of the construction.

The principal dimensions are :-

$\begin{array}{lllrrr}\text { Length between the rabbets at gunwale } & \ldots & \ldots & \text { Feet. } & \text { Inches. } \\ \text { Breadth, extreme } \ldots & \ldots & \ldots 7 & \text { II } \\ \text { Depth from top of keel to gunwale amidships } & \ldots & 5 & 9\end{array}$

The vessel is clinker built, and the material all oak. There are sixteen strakes of outside planking, the ordinary thickness 1 inch, average breadth amidships $9 \frac{1}{2}$ inches, including I inch land. The lengths vary from 8 to 24 feet. The scantling is not, however, uniform throughout; thus the tenth plank from the keel is about 8 inches broad and $I_{\frac{3}{4}}$ inches thick, and forms a shelf for the beam-ends. The fourteenth plank from the keel, or third from the top, is about Io inches broad and $I \frac{1}{4}$ inch thick. This plank, which we may call the "main wale," is perforated with holes for the oars, sixteen on each side, about 4 inches diameter, and provided with a slit at the after and upper edge to allow the blades of the oars to be passed through from inboard. The two upper strakes are the thinnest of all, being scarcely more than $\frac{3}{4}$ inch. The gunwale, 3 inches by $4 \frac{1}{2}$ inches, is placed in the usual manner insicle the top strake. The boards are throughout united to each other by iron rivets about the thickness of an ordinary 3 inch spike, spaced from 6 to 8 inches, with large flat heads $I$ inch diameter. The riveting plates are square or nearly so, $\frac{3}{4}$ inch. The nails are driven from the outside, except near the ends, where riveting inside would have been difficult from the sharpness of the vessel. The nails are here driven from the inside and riveted outside. The garboard strake is fastened to the keel with rivets of the same kind as those used for joining the strakes with each other.

The keel is of a peculiar shape; it is about 14 inches deep, of which II inches are belcw the rabbet, $4 \frac{1}{2}$ inches thick at the lower edge, and only 3 inches at the rabbet. The top of the keel is 7 inches broad, thus affording a large surface for the garboard strake, besides combining strength with lightness. Possibly also the increased thickness of the lower edge may have been adopted to improve weatherliness under sail. It is difficult to say where the keel ends and the stem and sternpost begin, as these run into each other with a very gentle sweep; but the piece of wood which may be called the keel proper is 57 feet long; to it are joined a short forefoot and heel piece by short vertical scarfs secured by double rows of rivets. These pieces again are fitted in a similar manner to the stem and stern-post. The posts are sided 3 inches, chamfered to 2 inches outside edge. They are $15 \frac{1}{2}$ inches broad outside the rabbet just above the scarf, decreasing in breadth upwards.

The framing of the bottom consists of grown floors extended in one piece from shelf to shelf. The average spacing in the body of the vessel is about 3 feet 3 inches from centre to centre, greater at the ends: there are nineteen frames in all. The floors are neatly finished, of a shape which combines strength with lightness and elasticity. The lower surface has a flat projection in which are holes for receiving the fastenings for the plank. The way these fastenings are managed is very peculiar. The 
planks are evidently worked down from stout slabs, and in doing so a ledge an inch high has been left on the inner surface running along the middle of the plank. The floors are not fayed down on the boards; they have only two points of contact with them, the upper edges and the ledge above mentioned, in which are two holes bored transversely, one on each side of the timber. Through these holes and corresponding holes in a fore and aft direction through the timbers are passed ties made of the tough roots of trees. These ties are very slight, scarcely $\frac{1}{4}$ inch diameter; they are crossed over the ledge on the board, only passing once through each hole. The ledge has been removed in the spaces between the timbers, so that the remaining parts under the timbers look like cleats fastened to the plank. With the exception of a nail driven through the "shelf" and riveted on the extreme end of the floors, these ties seem to be the only fastenings used at this part of the vessel. The floors are only about 4 inches diameter, a foot from the garboards, and taper, siding as well as moulding, down to 3 inches or even less at the shelf. They are not fastened to the keel.

As already stated, the beams, which are sided 7 irches, moulded 4 inches, rest on what Mr. Archer has called the "shelves," which however only differ from the ordinary planking by being $\frac{3}{4}$ inch thicker, and of greater lengths, the longest piece being about 48 feet. The beam-ends also rest on the ends of the floor timbers. They are secured by knees extending down the ship's side from the upper edge of the "main wale" with an arm on the beam. These knees are fitted close to the planking at the side, and fastened with oak trenails. Being a little narrower than the beams, a ledge is formed on each side for the bottom boards or flooring, which is made to fit into these ledges from beam to beam, thus forming a continuous platform. A strip of wood is nailed on top of the beams in continuation of the knees where these are too short to welt from opposite sides. The beams are supported amidships by pillars resting on the throats of the floors. The top sides, consisting of the two thin boards already mentioned, are connected with the body of the ship by independent timbers intervening between the knees, and extending from the under side of the gunwale some distance down the side, but not so far as the platform. There are no timbers in the upper part of the vessel, overlapping or making a shift with the floors.

It will be seen that by this system of construction the upper portion of the ship is altogether unconnected with the bottom part, so far as framing is concerned, an arrangement which would scarcely be safe where much ballast or a heavy cargo is carried on the ship's bottom. No doubt heavy weights when carried were placed above the platform, in which case there would not be the same tendency for the two sections to part company.

Perhaps the most singular part of this singular ship is the arrangement for stepping and supporting the mast. The step is a solid log of oak I I feet long and 19 inches broad by 14 inches deep at the middle, tapering to the ends. It is counter-sunk over the throats of the floors, to which it is fastened by means of small knees on either side. From this trunk a branch grows out vertically in front of the mast and quite close to it. This branch, which is nearly 12 inches thick, is fastened to what Mr. Archer has called the "fish."

The fish is a ponderous piece of oak lying along the middle line of the vessel, on top of the beams, and extending over five spaces. It is 16 feet long, 38 inches broad, and 14 inches deep at the middle. This block is modelled so as to represent the tails of two fishes or whales resting on a flat slab or sole piece about 4 inches thick. The slab is counter-sunk over the keams and well

I This mode of binding the two sides together by means of beams half way between gunwale and keel is still practised in the west and north of Norway. Even small skiffs are tied together in this way, loose thwarts being placed over the beams, only resting in a notch cut in the knees which secure the beams, while the foor-tiplers merely butt up against tre beams. secured to them by knees. A large slice is taken off the back of the fish, the upper surface thus forming two planes inclining to either end. The extreme ends of the tails are only about 3 inches thick above the slab. A slot 5 feet 9 inches long and $12 \frac{1}{2}$ inches wide (the diameter of the mast) is cut in the fish from a point a little in front of the middle towards the stern. The mast is stepped through the forward end of this slot, and when erect kept in its place by a heavy slab fitted into the slot. In the end view this slab is shown with the after end raised level with the forward end. By removing the slab and slacking off the fore-stay the mast would be free to fall aft in the slot, and could thus easily be lowered. In order that the beam nearest the mast should not interfere with this manœuvre there is a depression in it which enables the mast to fall back the whole length of the slot. ${ }^{1}$ There is a stanchion about 8 feet high, with a cross-beam at top in which are semicircular depressions for the spars to rest in when not in use. There have been three such stanchions.

The mast, which is $12 \frac{1}{2}$ inches diameter, has been cut about to feet from the foot. The extreme top of one of the spars found in the ship, corresponding in size to the part which remains, has rotted away; but if this spar, as seems probable, is the upper portion of the mast, the whole length may have been 40 feet. There is another spar which looks as if it might have been the yard. It is broken off near the middle, but Mr. Archer estimates its full length at 35 feet, diameter at slings $8 \frac{1}{2}$ inches, at arms $3 \frac{1}{2}$ inches. Abreast of the forward end of the fish, strong pieces of wood, one on either side, each with two circular sockets, are fitted down between the timbers just above the platform. Possibly one of these sockets may have served as a step for a squaresail boom. The other may have received a pair of shears to give elevation to the fore stay when raising or lowering the mast.

With regard to the rudder, a conical piece of wood sufficiently long to keep the rudder clear of the ship's side is fitted with its base to the outside planking; through a hole bored through the centre of the cone, and a corresponding hole in the rudder, a stout rope is rove, provided with a knot at the outer end and made fast inboard. This rope acts as a pivot, allowing the rudder to be twisted by means of the tiller fitted athwartships. An iron staple near the lower extremity of the rudder, and a small ring bolt at the upper end may have been fitted with guys leading aft to steady the rudder and keep it immersed when the ship was under way. The rudderhead or stem is round, 6 inches diameter. At the pivot it is 7 inches thick, thence decreasing in thickness downwards. The breadth is 15 inches at pivot, increasing to 22 inches at foot. Both edges are bevelled off, particularly the front one, which is reduced nearly to a feather edge. The rudder is all of one piece of wood.

The extreme ends of the vessel are unfortunately gone, so that it is not easy to see how she has been finished off here. The lower planking takes a very decided turn upwards as it approaches the ends, running in fact almost parallel with the posts. If therefore all the wood ends have joined the posts, these must have been very high. It seems not improbable that part of the planking has been received into a rabbet in the gunwale, or in a breasthook connecting the gunwale with the stem or sternpost. This however is merely a conjecture.

If the old ship can be looked upon as a fair sample of the ships of her time, it is evident that shipbuilding a thousand years ago was something very different from what we now understand by that term. What strikes one most forcibly on seeing this vessel as she now stands is the extreme lightness of her scantling and the total absence of anything in the shape of lining, longitudinal stringers, or similar contrivances for giving what we

$x$ In the Scandinavian languages the technical term for the framing which now takes the place of this colossal structure in our modern ships-the mast partners-is still Fisken, the fish. 
should consiler the strength and rigidity necessary in a sea-going vessel. It would however be unfair to compare her with a ship of modern build of the same size. Even the designation "ship," as applied to her, is apt to convey a false idea. She is in fact a very large sailing rowingboat.

These ancient vessels may be considered as consisting of two distinct sections, each having its special use and function. The portion above the beams is the hold proper, the useful space. Here the crew had their abode, and here was carried probably all that the vessel had to carry, and this portion is comparatively strong. The material is no doubt here also of small dimensions, but what there is has been judiciously distributed, is of good quality, and has been well put together. It should also be remembered that the weight carried was small in quantity as compared to the carrying capacity, and consisted principally of live cargo, and this kind of loading is much less trying to a vessel in a seaway than a similar loading of dead weight would be. The lower portion of the ship, on the other hand, had a different kind of duty to perform. It had to supply the "form" necessary for small resistance and rapid locomotion, and to float the upper section : keeping this in mind it will be found that her construction gives evidence of a great deal of practical skill and ingenuity. Every part of the vessel is sufficiently strong for the duty expected of her, while at the same time economy of weight of material has been studied throughout. It will be seen that the weight of the superstructure is taken entirely by the floor timbers, the ends of the beams resting on them, while the beams are supported amidships by the props stepped in the throats of the floors. There would therefore be very little stress on the ties of the bottom planking, which latter, there being no counteracting pressure on it from the inside, would always tend to cling to the timbers by the pressure of the water outside. The only weight of any moment which would tend to separate the two sections of the boat is the mast, and this tendency is met by the "branch" of the step being secured to the "fish." Still there can be no doubt that this boat must have possessed a pliancy and mobility in a heavy sea which we should look upon as ominous in a modern sea-going craft. Her real safety consisted in a tough and elastic outer skin, which would be the more invulnerable from not being made unduly rigid at any point. Thus her apparent weakness was her real strength. Mr. Archer has not been able to discover anything deserving the name of a bolt in the whole structure. The stoutest iron fastenings are the rivets in the scarfs of the keel and the nails securing the inside knees, and they are no stronger than ordinary 4 -inch spikes.

It seems probable that such a boat would be capable of great speed, even under oars alone; with a fair wind she must have been very fast. Mr. Archer has assumed a low water-line, and finds that at this trim her displacement is 994 cubic feet, or 28.4 tons; area of immersed midships section 24 square feet; extreme length on loadline, 73 feet 3 inches; and draft of water 3 feet 8 inches. Allowing ro tons for her complement of 10o men with their accoutrements, leaves 184 tons for the vessel, with inventory, stores, and equipment, and this allowance is probably ample. The areas of cross-sections are obtained by multiplying the ordinates of the curve by 4 feet.

\section{LEARNED SOCIETIES IN JAPAN}

$I^{\mathrm{T}}$ is now a little more than ten years since Japanese students began to flock in large numbers to the various schools of Europe and America, after the great revolution which completely altered the political, and in many respects the social, organisation of the country. Many of these young men travelled and studied at their own expense; but the majority was selected by the principal Government departments, and the expenses paid from the Imperial funds. For six or seven years the numbers continued without diminution; but soon after the commencement of the Satsuma rebellion in 1877 when the heavy strain on the Imperial Exchequer caused by the suppression of that outbreak began to be felt, it was decided to economise the public expenditure in various ways, and amongst others by reducing the number of those studying abroad at Government expense. The result of this measure, which was forced on the Ministers by unfortunate circumstances, was that many Japanese young men who spent some years in the principal educational establishments of western countries, returned to their own land with a sound training in their respective branches of study. It would not be desirable, even if it were possible, to enter here into the question how far they have fulfilled the hopes with which they were first sent abroad. Many of them have had brilliant careers amongst their foreign fellow-students, and, on the whole, we believe they have done as much as any body of English students, similarly placed, could have in the same time; but it is another question whether they are fitted to assume the places held by the foreign professors and instructors in the various educational institutions of the country. It was to this that the Government looked when they were first despatched to Europe ; but, from a combination of causes, it is doubtful whether the laudable and patriotic desire to be, as far as possible, independent of extraneous assistance, has been so completely fulfilled as was originally anticipated.

One result has undoubtedly attended this great influx of men trained after western methods, namely, the thirst for scientific knowledge of all kinds amongst the educated classes in Japan. It is hardly an exaggeration to say that Japanese literature, as an indigenous product, is for the present almost in abeyance. If we examine the monthly catalogue of books for which licence to print is granted by the Censorate in the Home Department in Tokio, it will be seen that a very large proportion is composed of translations or adaptations of European or American scientific or literary works. Besides translations made at the expense of the public departments, we find private individuals throughout the country utilising their knowledge of a western language by translating from it, for the benefit of their countrymen. Thus, not to mention innumerable "Lives" of Wellington and Napoleon, or translations of "Gulliver's Travels," "Robinson Crusoe," and other books of this description, the works of Huxley, Carpenter, Peschel, Darwin, 'Tyndall, Quatrefages, Lyell, Buckle, Mill, \&c., \&c., have all been translated or adapted with more or less success for the Japanese reader. Societies, on the European model, have also been formed, and it is with these that we are chiefly concerned at present.

Centuries before the Royal Society of Great Britain was founded men interested in the pursuit of some study or accomplishment in Japan had formed themselves in to societies, some of which still exist. Collectors of antiquities, of coins, of the handwriting of celebrated men of ancient times, met at stated intervals to exhibit and discuss the authenticity of their treasures; go-players had their own organisation, with branches in all the chief towns throughout the country, and headquarters in the capital, where the leaders met for trials of skill. These latter even had a kind of magazine in which problems for solution were set, and the moves in remarkable games recorded. These meetings generally took place in the evening, at some well-known house of entertainment. There was no formal reading of papers, with discussions afterwards ; a member exhibited some new object, related briefly all he knew about it, and asked for any further information that could be afforded by those present. Frequently also these meetings were used for effecting 